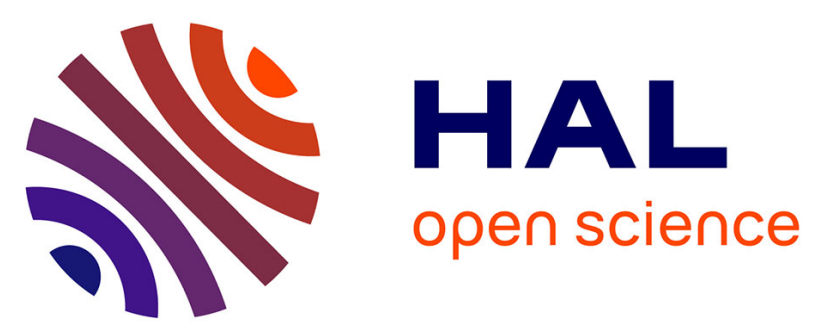

\title{
Construction of a reference linkage map of Vitis amurensis and genetic mapping of Rpv8, a locus conferring resistance to grapevine downy mildew
}

Sophie Blanc, Paule Blasi, Sabine Merdinoglu-Wiedemann, Emilce Prado, Pedro-Felipe Mestre Artigues, Didier Merdinoglu

\section{To cite this version:}

Sophie Blanc, Paule Blasi, Sabine Merdinoglu-Wiedemann, Emilce Prado, Pedro-Felipe Mestre Artigues, et al.. Construction of a reference linkage map of Vitis amurensis and genetic mapping of Rpv8, a locus conferring resistance to grapevine downy mildew. Ecole chercheurs "Génomique et Diversité des Caractères à déterminisme complexe", 2011, NA, France. hal-01605480

\section{HAL Id: hal-01605480 \\ https://hal.science/hal-01605480}

Submitted on 6 Jun 2020

HAL is a multi-disciplinary open access archive for the deposit and dissemination of scientific research documents, whether they are published or not. The documents may come from teaching and research institutions in France or abroad, or from public or private research centers.
L'archive ouverte pluridisciplinaire HAL, est destinée au dépôt et à la diffusion de documents scientifiques de niveau recherche, publiés ou non, émanant des établissements d'enseignement et de recherche français ou étrangers, des laboratoires publics ou privés. 


\section{Construction of a reference linkage map of Vitis amurensis and genetic mapping of Rpv8, a locus conferring resistance to grapevine downy mildew}

Sophie BLANC ${ }^{1}$, Paule BLASI ${ }^{1}$, Sabine WIEDEMANN-MERDINOGLU ${ }^{1}$, Emilce PRADO ${ }^{1}$, Ernst H. RUHL ${ }^{2}$, Pere MESTRE ${ }^{1}$, Didier MERDINOGLU ${ }^{1}$

${ }^{1}$ INRA-UDS, UMR 1131 Santé de la Vigne et Qualité du Vin, 28 rue de Herrlisheim, Colmar, F-68021 cedex, France ${ }^{2}$ Hochschule RheinMain, Geisenheim Research Center, von-Lade-Str. 1, 65366 Geisenheim, Germany

\section{Abstract}

Downy mildew, caused by the oomycete Plasmopara viticola, is one of the major threats to grapevine. All traditional cultivars of grapevine (Vitis vinifera) are susceptible to downy mildew, the control of which requires regular application of fungicides. In contrast, many sources of resistance to $P$. viticola have been described in the Vitis wild species, among which is $V$. amurensis Rupr. (Vitaceae), a species originating from East Asia.

To measure the general level of resistance, the sporulation of $P$. viticola and the necrosis produced in response to infection, five quantitative and semi-quantitative parameters were scored 6 days post-inoculation (dpi) on a V. amurensis S1 progeny (Table 1, Fig. 1, Fig.2).

A genetic linkage map of $V$. amurensis, based on 122 simple sequence repeat and 6 resistance gene analogue markers, was established using the same S1 progeny. This map covers $975 \mathrm{cM}$ on 19 linkage groups, which represents $82 \%$ of the physical coverage of the $V$. vinifera reference genetic map (Fig. 3).

A quantitative trait locus (QTL) analysis allowed us to identify on linkage group 14 a major QTL controlling the resistance to downy mildew found in $V$. amurensis, which explained up to $86.3 \%$ of the total phenotypic variance. This QTL was named 'Resistance to Plasmopara viticola 8' (Rpv8).

\section{Analysis of downy mildew resistance traits}

\begin{tabular}{|c|c|c|}
\hline Variable name & Description & Scoring \\
\hline OIV452 & $\begin{array}{l}\text { Symptom-based semi-quantitative scoring of downy } \\
\text { mildew resistance adapted from the criteria of the } \\
\text { Office International de la Vigne et du Vin (OIV; } \\
\text { Anonymous } 2009 \text {; } \text {;ttp://news.reseau- } \\
\text { concept.net/images/oiv/client/Code_descripteurs_2ed } \\
\text { FR.pdf) }\end{array}$ & $\begin{array}{l}\text { From } 1 \text { (very susceptible) to } 9 \text { (totally resistant) (Figure1): } \\
1=\text { abundant sporulation densely covering the whole disc } \\
\text { area, absence of plant necrosis } \\
3=\text { abundant sporulation present in large patches, absence } \\
\text { of plant necrosis } \\
5=\text { = limited sporulation present in intercostal patches, } \\
\text { necrotic flecks or speckles } \\
7=\text { sparse sporulation, necrotic spots } \\
9=\text { no sporulation, absence of necrosis or necrotic points }\end{array}$ \\
\hline SDSC & Percentage of sporulating leaf discs & From 0 to $100 \%$ \\
\hline SPNB & $\begin{array}{l}\text { Number of sporangia per } \mathrm{cm}^{2} \text { of leaf disc measured } \\
\text { with a Z2 Coulter Counter (Beckman Coulter). }\end{array}$ & $\begin{array}{l}\text { Quantitative. Number of sporangia per } \mathrm{ml} \text { of suspension } \\
\text { converted to number of sporangia per } \mathrm{cm}^{2} \text { of leaf disc }\end{array}$ \\
\hline NSURF & Visual semi-quantitative scoring of necrotized surface & From l (very large) to 9 (very small) (Figurel) \\
\hline NDSC & Percentage of necrotized discs & From 0 to $100 \%$ \\
\hline
\end{tabular}

Table 1. Variables scored to assess the resistance level to downy mildew.

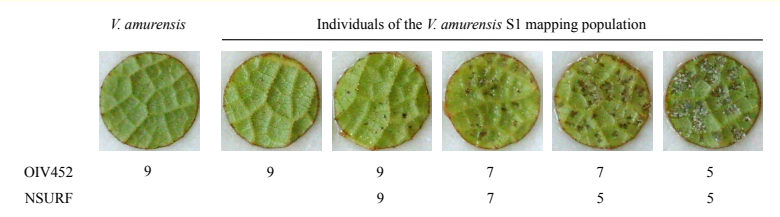

Fig. 1 Range of the segregating phenotypes more commonly observed $6 \mathrm{dpi}$ on $1 \mathrm{~cm}$ leaf discs in the $V$. amurensis $\mathrm{S} 1$ mapping population. The traits describing the necrotic symptoms produced in response to infection are linked to the resistance level parameters: the higher the resistance, the weaker the necrotic response to infection.

\section{First genetic map of an asian Vitis species : V. amurensis}

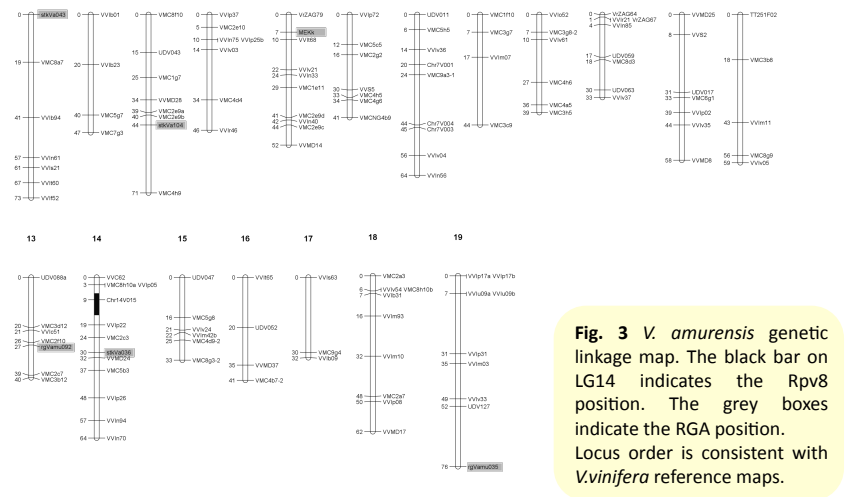

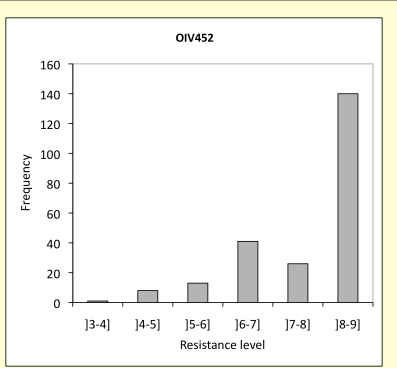

Fig. 2 Distribution of the variables scored in the V. amurensis $\mathrm{S} 1$ population.

Resistance to downy mildew display a continuous variation and segregate as a quantitative trait. OIV452, SDCS and SPNB display segregation patterns where sixty percent of the individuals are totally resistant, the remaining part of the population showing various levels of partial resistance. This segregation suggests that the differences in resistance to downy mildew observed in the $\mathrm{S} 1$ population from to downy mildew observed in the $\mathrm{S} 1$ population from
$V$. amurensis are controlled by a dominant major V. amurensis are controlled by a dominant major
locus together with minor quantitative loci, the latter modulating the resistance level for the individuals that do not carry the major factor.
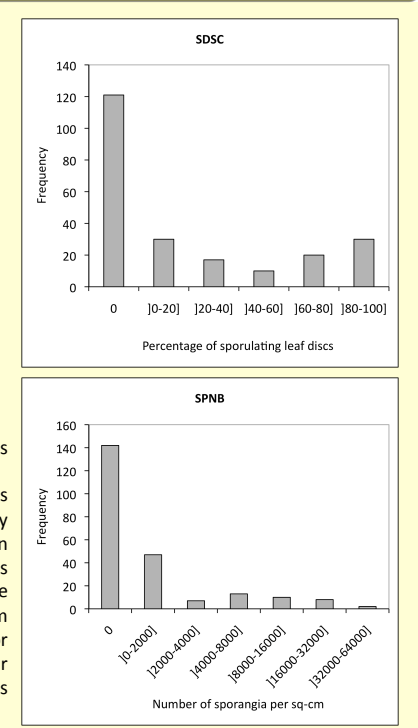

\section{QTL detection}

A major QTL controlling resistance to downy mildew was detected on LG14 for OIV452, DSCS and SPNB. Analysis based on DSCS gave the highest LOD score (65.45) and explained $86.3 \%$ of the total phenotypic variance and thus $100 \%$ of the genetic variance, considering the broad sense heritability estimated at $86.2 \%$.

The locus at this position was denoted 'Resistance to Plasmopara viticola 8' (Rpv8).

The genome interval between the markers VVIp05 and VVIp22 that flanks the Rpv8 confidence interval covered a physical distance of $15.11 \mathrm{Mb}$, which encompasses 502 genes, according to the $12 \mathrm{X}$ grape genome sequence (http://www.genoscope.cns.fr/externe/ Genome-Browser/Vitis/).

A minor QTL was detected for OIV452 and located on LG15.

A second minor factor was detected for NSUR on LG17.

\section{Conclusions}

This paper reports the first grapevine genetic linkage map based on an intra-specific progeny of a Vitis species other than $V$. vinifera. $V$. amurensis map and the previously published $V$. vinifera maps share a high level of macro-synteny.

Furthermore, our work allowed us to identify on LG14 a new major QTL controlling resistance to downy mildew in V. amurensis, named Rpv8. This locus is located on a genomic region never previously described to control downy mildew resistance in grapevine and related Vitis species. 